BOTANICA

ISSN 2538-8657

2020, 26(2): 138-149

\title{
POVILAS SNARSKIS' COLLECTION OF THE POACEAE SPECIMENS, NEWLY DISCOVERED IN THE HERBARIUM OF VILNIUS UNIVERSITY
}

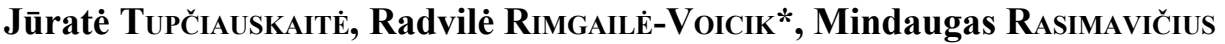

Vilnius University, Life Sciences Centre, Institute of Biosciences, Sauletekio Av. 7, 10257 Vilnius, Lithuania

*Corresponding author. E-mail: radvile.rimgaile-voicik@gmc.vu.lt

\begin{abstract}
Tupčiauskaitė J., Rimgailè-Voicik R., Rasimavičius M., 2020: Povilas Snarskis’ collection of the Poaceae specimens, newly discovered in the Herbarium of Vilnius University. - Botanica 26 (2): 138-149.

We newly found a collection of the Poaceae specimens deposited at the Herbarium of Vilnius University (WI), collected by Povilas Snarskis mainly from eastern Lithuania in 1943-1960. The collection consisted of 67 herbarium sheets representing 28 species, including endangered species Glyceria lithuanica. The collection provided new data on abnormal growth forms of common Lithuanian grasses and the distribution of rare and endangered Poaceae species in eastern and southern Lithuania. The discovered Glyceria lithuanica specimen is the oldest of all known records of the species in Lithuania.
\end{abstract}

Keywords: abnormal growth forms, commelinids, Glyceria lithuanica, Koeleria, Vilnius Region.

\section{INTRODUCTION}

The Commelinidae family Poaceae (R. Br.) Bernhart (Gramineae Juss.) comprises up to 12.000 species worldwide (KellogG, 2015; Soreng et al., 2017), with more than 110 species native to Lithuania (GudžInSKAs, 1999). The Poaceae, the fifth most species-rich family of flowering plants, is viewed as a natural model system with highly repetitive morphology elements (Vorontsova et al., 2015). The taxonomy of the Poaceae species includes many ambiguities, and specimen identification requires dedication. The flowers of grasses are anemophilous and aggregated into spikelets, which then form terminal racemose or paniculate inflorescences. The features of glumes, florets (lemmas and paleas), and lodicules are highly diverse and used by taxonomists to describe and classify grasses (NATKEVIČAITĖ-IVANAUSKIENĖ, 1963; Clayton et al., 2006). Herbarium collections of the Poaceae species make current taxonomic work possible, and worldwide, there are 5.605.757 preserved specimen records entered to the Global Biodiversity
Information Facility (GBIF, 2020). The total number of the Poaceae specimens in Lithuanian herbaria is unknown.

Traditionally, herbaria collections are viewed as pivotal for studies of taxonomy and provide baseline data on diversity (NATKEVIČAITÉ-IVANAUSKIENÉ, 1994; BEBBER et al., 2010). The biological collections of academic institutions have made countless contributions to science from environmental monitoring to traditional taxonomy and systematics and are increasingly being recognised as a unique and underused resource (Berendsohn \& Seltmann, 2010; FunK, 2014; James et al., 2018). It is not uncommon for botanists to leave incompletely identified herbarium specimens that are later forgotten. The ongoing, worldwide, large-scale digitisation projects for increasing accessibility to biodiversity data enhances the pace of herbaria analyses with new species being described each year from specimens that have been housed in collections for decades (SolTis et al., 2018).

In 2016, when the Herbarium of Vilnius University (WI) was moved to a new modern depository 
at the Life Sciences Centre, a long-lost Bryophyte collection was analysed (JUKONIENĖ et al., 2018; RASIMAVIČIUS, 2018). At the same time, a stack of 61 herbarium sheets lacking fully identified specimens of grasses collected by Povilas Snarskis in 1943-1960 was discovered. Professor P. Snarskis (1889-1969) was an insightful researcher of Lithuanian flora, taxonomist and plant geographer (TUPČIAUSKAITĖ \& Rimgailé-VoiciK, 2020). This study aimed to identify the discovered collection of P. Snarskis, and provide new knowledge about the morphological variation of the Poaceae species included in this collection, and present their current distribution in Lithuania.

\section{MATERIALS AND METHODS}

The specimens were identified using previously published information (NATKEVIČAITĖ-IVANAUSKIENĖ, 1963, 1980; Tzvelev, 1974, 2000; Vovk, 1977; Conert, 1998; GudžInSKAS \& SinkeviČIENĖ, 2002; SinkeviČIENĖ, 2003; Rothmaler et al., 2005; GoreMYKINA, 2013). Where appropriate, the nomenclature follows GuDžINSKAs (1999), and interspecies taxa were identified according to CONERT (1998) and NatKeviČaitė-IVanauskienĖ (1980). To categorise the rarity or abundance of the species and general characteristics, such as size and occurrence frequency, we followed KuUsK et al. (2003).

Diagnostic features were checked using an Olympus SZXZ stereo microscope and an Olympus CH40 microscope. Leaf thin sections for Koeleria Pers. specimens were cut by hand in the middle of the leaf and analysed using an Olympus SZ61 stereo microscope. To facilitate additional comparisons among Koeleria specimens, two other Koeleria herbarium specimens were sectioned and viewed using a microscope, K. delavignei Czern. ex Domin and K. pyramidata (Lam.) P. Beauv. Detailed images were captured with a Pixelink camera.

After identifying the specimens, we compiled a descriptive list with the herbarium label information from P. Snarskis and notes made by the authors of this paper (Appendix 1). We presented the genera and species in alphabetical order. The specimens of Koeleria glauca (Spreng.) DC., which had highly variable leaf sections, were marked in the notes of the appendix with a question mark (?), indicating a level of uncertainty.

\section{RESULTS}

\section{General characteristics of the Poaceae collection}

The original collection consisted of 61 herbarium sheets. The specimens were not mounted on paper, and some herbarium sheets contained several dried specimens. Almost all collection labels were written in ink and corresponded to the handwriting of P. Snarskis (Fig. 1B). Five labels were not written by P. Snarskis, but one of these five labels was signed by him (Fig. 1A). On the labels of two unidentified specimens (Appendix 1; No. 4, No. 43) and one separate sheet of paper (Appendix 1; No. 9), P. Snarskis left pencil notes indicating specific specimen characters or a plausible taxon. The specimens were analysed attentively by the collector so that the characters needed for identification would be better visible in dried material: some specimen leaf ligules were highlighted before drying, and one Agrostis L. specimen had the number of lemmas accentuated.

Based on the data presented in the herbarium labels, the largest part of the collection (89\%) was plants collected from eastern Lithuania, mainly from Vilnius Region. The specimens had been collected over 12 years, with varying levels of collection intensity. Specifically, the specimens were collected in 1943, 1946, 1948-1953, 1955-1956, 1958, and 1960.

Twenty-eight localities were mentioned in the herbarium labels (Appendix 1). The largest number of specimens was collected near the Vilnius-Daugavpils railway $(31 \%)$. Twenty-eight percent of the specimens were collected in Vilnius and within a radius of 20 kilometres from the city (28\%), with several other specimens collected in Druskininkai (15\%) and Palanga $(10 \%)$. Other localities were also along the railway lines of Vilnius-Kaunas (6.5\%), Vilnius-Varèna (5\%), Radviliškis-Daugavpils (3\%), and Kaunas-Kybartai (1.5\%). Plants were collected near train stops or up to a few kilometres away from the train line.

The habitats described on the labels fall into these major categories: forests (mainly pine forests; $61 \%$ of herbarium sheets), meadows (18\%), secondary habitats (railroad embankments, roadsides, and near cultivated fields; $11 \%)$, and bogs and riversides (10\%).

\section{Analysis of collection diversity}

After examination, the number of herbarium sheets increased from 61 to 67 , because two differ- 


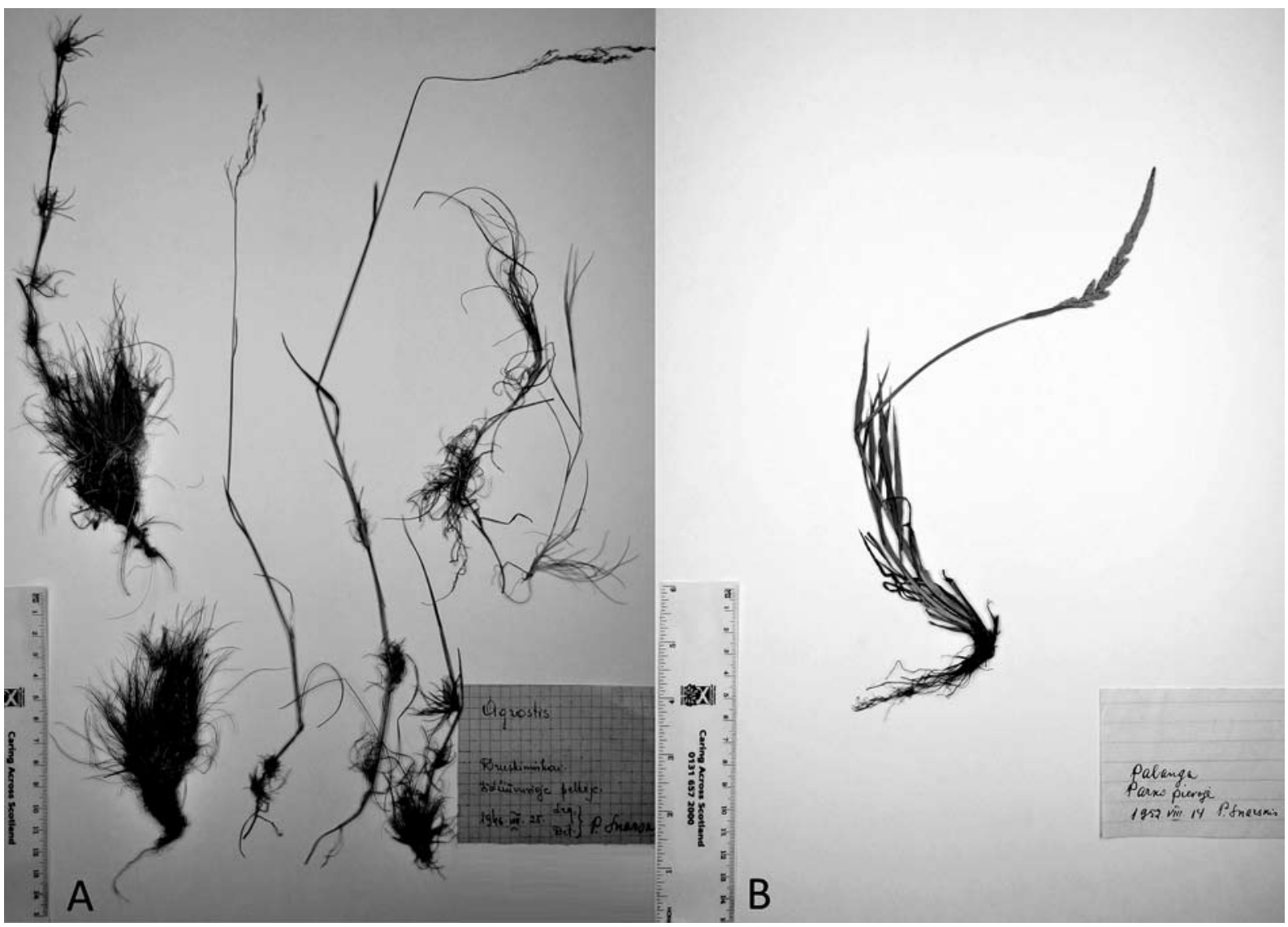

Fig. 1. Atypical Poaceae specimens collected by P. Snarskis: not fully identified (A) and unidentified specimens (B)

ent species were found placed together in six herbarium sheets (Table 1). Only one specimen, Koeleria gracilis Pers., in the analysed collection was identified to species level by P. Snarskis. In 47 herbarium sheets, P. Snarskis identified the plants to level of genus: Koeleria (23), Agrostis (10), Calamagrostis Adans. (four), Poa L. (three), Alopecurus L. (two), Bromus L. (two), Festuca L. (two), and Lolium L. (one). In 13 herbarium sheets, specimens were left unidentified.

After analysing the collection, the number of the collected genera increased from eight to 17 (Table 1). Additional genera were: Anisantha K. Koch, Bromopsis (Dumort.) Fourr., Catabrosa P. Beauv., Corynephorus P. Beauv., Glyceria R. Br., Milium L., Molinia Schrank, Phleum L., and Trisetum Pers. The genus Anisantha was included in the list because of a nomenclature change (ScHOLZ, 2008); the collection was correctly identified by P. Snarskis and treated as Bromus.
A total of 28 species were determined in the collection: Agrostis canina L., A. capillaris L., A. ×murbeckii Fouill., A. stolonifera L., A. vinealis Schreb., Alopecurus pratensis L., Anisantha tectorum (L.) Nevski, Bromopsis erecta (Huds.) Fourr., Bromus arvensis L., B. hordaceus L., Calamagrostis arundinacea (L.) Roth, C. canescens (F.H. Wigg.) Roth, C. stricta (Timm) Koeler, Catabrosa aquatica (L.) P. Beauv., Corynephorus canescens (L.) P. Beauv., Festuca ovina L. var. firmulacea (Markgr.-Dannenb.) Stohr, Festuca polesica Zapał., Glyceria lithuanica (Gorski) Gorski, Koeleria glauca (Spreng.) DC., $K$. grandis Besser ex Gorski, Lolium temulentum L., Milium effusum L., Molinia caerulea (L.) Moench, Phleum phleoides (L.) H. Karst., Poa annua L., P. palustris L., P. trivialis L., and Trisetum sibiricum Rupr. The highest number of species was attributed to Agrostis, Calamagrostis, and Poa (Table 1). Two Koeleria specimens were determined to genus level. More than a third of P. Snarskis collection con- 
Table 1. The summary of species and herbarium sheet numbers before and after the analysis of P. Snarskis collection

\begin{tabular}{|c|c|c|c|c|}
\hline \multirow{2}{*}{ Genera } & \multicolumn{2}{|c|}{ Before identification } & \multicolumn{2}{|r|}{ After identification } \\
\hline & Species & Herbarium sheets & Species & Herbarium sheets and their previous history \\
\hline Agrostis & $\mathrm{N} / \mathrm{A}$ & 10 & 5 & $9+3$ (unidentified) +1 (mixed in a sheet with other species) \\
\hline Alopecurus & N/A & 2 & 1 & 2 \\
\hline Anisantha* & N/A & $\mathrm{N} / \mathrm{A}$ & 1 & 1 (other genus) \\
\hline Bromopsis** & N/A & N/A & 1 & 1 (unidentified) \\
\hline Bromus & N/A & 2 & 2 & $1+1$ (unidentified) \\
\hline Calamagrostis & N/A & 4 & 3 & $\begin{array}{l}4+1 \text { (unidentified) }+1 \text { (other genus) }+1 \text { (mixed in a sheet } \\
\text { with other species) }\end{array}$ \\
\hline Catabrosa** & N/A & N/A & 1 & 2 (unidentified) \\
\hline Corynephorus** & N/A & N/A & 1 & 1 (unidentified) \\
\hline Festuca & N/A & 2 & 2 & 2 \\
\hline Glyceria** & N/A & N/A & 1 & 1 (unidentified) \\
\hline Koeleria & 1 & 23 & 2 & $24+2$ (mixed in a sheet with other species) \\
\hline Lolium & N/A & 1 & 1 & 1 \\
\hline Milium $^{* *}$ & N/A & $\mathrm{N} / \mathrm{A}$ & 1 & 1 (unidentified) \\
\hline Molinia** & N/A & $\mathrm{N} / \mathrm{A}$ & 1 & 1 (mixed in a sheet with another genus) \\
\hline Phleum** & N/A & $\mathrm{N} / \mathrm{A}$ & 1 & 1 (unidentified) \\
\hline Poa & N/A & 3 & 3 & $3+1$ (mixed in a sheet with other genus) \\
\hline Trisetum $^{* *}$ & N/A & N/A & 1 & 1 (unidentified) \\
\hline
\end{tabular}

Symbols: * new genus because of nomenclature change; **-new genus after identification.

sisted of rare or uncommon species in Lithuania. Specifically, the collection contained: Agrostis vinealis, Bromopsis erecta, Bromus arvensis, Calamagrostis stricta, Catabrosa aquatica, Festuca polesica, Glyceria lithuanica, Koeleria grandis, Lolium temulentum, Phleum phleoides and Trisetum sibiricum.

\section{Atypical growth forms}

The largest part of the collection highlights the Poaceae specimens with morphological features not typical to the given taxon in size, colour or atypical growth form (Fig. 1). Bromus hordaceus, Catabrosa aquatica (Appendix 1; No. 28), Milium effusum and Poa annua were taller than average or almost at the maximum of known height. Calamagrostis arundinacea, Koeleria glauca (Appendix 1; No. 35) and Phleum phleoides (Fig. 1B) were shorter than average. The specimens of unusual colour were divided into two categories: 1) previously described as intraspecific taxa (Appendix 1; No. 3, 4, 29); 2) caused by extreme growth conditions such as solar radiation (Appendix 1; No. 13, 20, 35, 41, 42, 53, etc.). Other unusual morphological features included Poa palustris with a branched stem, Catabrosa aquatica with remote lower panicle branches (Appendix 1; No. 28), and Koeleria glauca with elliptical panicles with elongated middle branches of the inflorescence (Appendix 1 ; No. 35) or an extended underground stem (Appendix 1; No. 34).

Among Calamagrostis canescens specimens, variation was also noticeable, mostly related to glume exterior features. The Calamagrostis specimens (Appendix 1; No. 21-24) collected represent the spectrum of $C$. canescens species. One of the specimens with unopened greenish panicles was provisionally identified by P. Snarskis as Agrostis (Appendix 1; No. 21).

An unusual specimen of Agrostis (Appendix 1; No. 9) was reclassified to $A$. ×murbeckii Fouill. (A. capillaris $\times A$. stolonifera). In the present territory of Lithuania, this hybrid was published as Agrostis $\times$ lithuanica Besser ap. Roem. et Schult., and three known localities were reported (NATKEVIČAITÉIvANAUSKIENE, 1963). P. Snarskis collected an unusual specimen of Agrostis (specimen No. 9) seven years earlier than the available data on this hybrid in present day Lithuania. The A. capillaris $\times$ A. stolonifera hybrid is known to be common in flooding sites (Tzvelev, 1974; Conert, 1998) and is rather common in the Baltic countries (Krall et al., 2003a). The ligule in specimen No. 7 (Appendix 1) was $2 \mathrm{~mm}$ in length, triangular, panicle rachises clustered; under- 
ground horizontal stolon was $4 \mathrm{~cm}$ in length, with the tip broken off. Visually it was similar to specimen No. 9 and might be a hybrid (A. capillaris $\times$ A. stolonifera).

There were evident discrepancies in the hairiness, stem base thickenings, and lemmas shape of specimens identified as Koeleria glauca. Two specimens of Koeleria had highly complicated sets of traits (Appendix 1; No. 47, 48; Fig. 2, E) and were identified to the genus level. Specimen No. 48 had features similar to Koeleria glauca (vegetative shoots had more than four leaves; thickenings at the base of the stem were small, but present; lemma tips rounded), but other features (densely tufted, shoots curved like a bow; $1 \mathrm{~cm}$ long broken rhizome was present; leaves on the vegetative shoot up to $12 \mathrm{~cm}$ in length, partly curled) were more typical of Koeleria grandis. Because the features present in the specimen were not assigned to a species, the specimen was determined to the genus level.

The leaf cross-sections of $K$. glauca, $K$. grandis, $K$. delavignei and $K$. pyramidata were compared. The results of these comparisons suggested that the

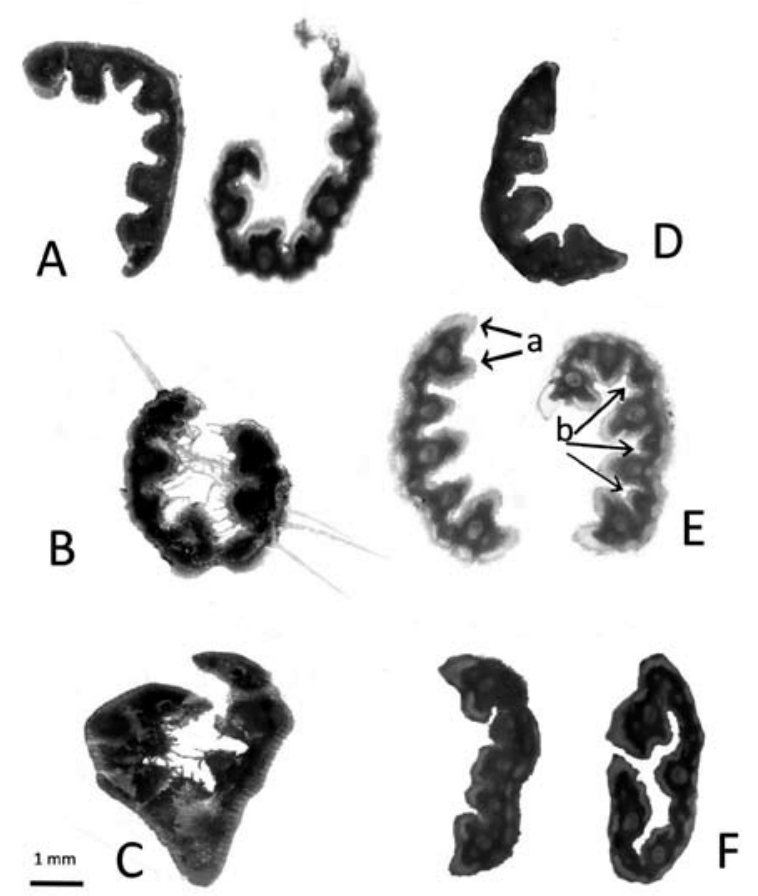

Fig. 2. Thin leaf cross-sections of Koeleria specimens: A $K$. pyramidata; $\mathrm{B}-K$. grandis; $\mathrm{C}-K$. delavignei; $\mathrm{D}-K$. glau$c a ; \mathrm{E}$ and F. - atypical $K$. glauca (in E arrows mark atypical ridges at the leaf edges (a) and in the central part of the leaf (b)) leaf cross-sections of $K$. glauca in P. Snarskis' collection had a wider morphological variation than is given in the description of the $K$. glauca leaf section (CONERT, 1998). Otherwise, leaf cross-sections representing different species are easily distinguished and can be used to determine Koeleria species (Fig. 2).

\section{DISCUSSION}

P. Snarskis' collection of the Poaceae species probably remained unidentified for three main reasons: 1) the tumultuous history of that period in Lithuania; 2) the possibility of some species being unknown in Lithuania; 3) the abnormal morphological features. First, during the interwar period, Lithuania was isolated from the south-eastern part of the country (Fig. 3). Until the autumn of 1939, Vilnius Region was a part of Poland, and Lithuania and Poland were officially at war for Vilnius between 1920 and 1938 (SNYDER, 2003). In 1940, the decision was made to move the Faculty of Mathematics and Natural Sciences from the temporary capital Kaunas to Vilnius and re-establish Vilnius University (KLIMAVIČIŪTÉ, 2002). After 1939, Vilnius Region, with its unique geomorphological conditions and habitats of northeastern and south-eastern sandy plains (BASALYKAS, 1965), became available for research.

Second, it is possible that some species were un-

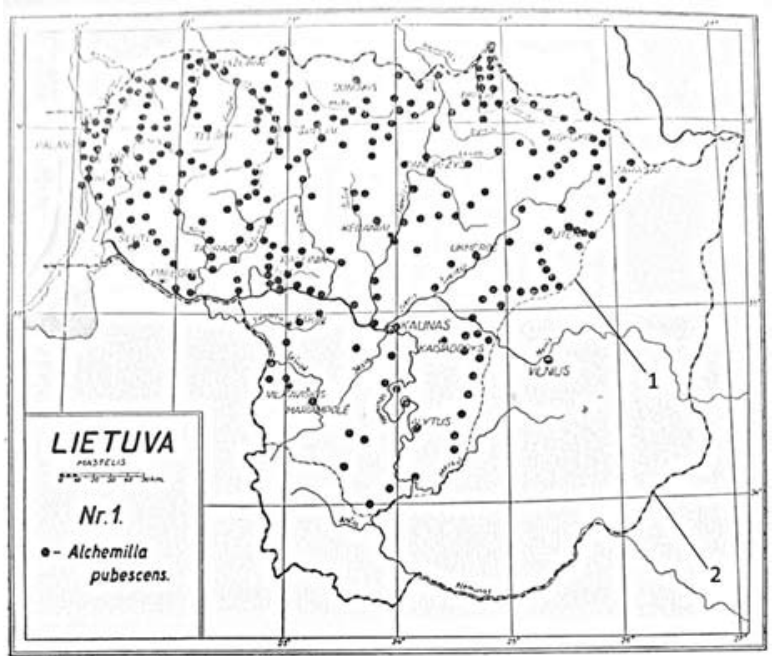

Fig. 3. Distribution map of Alchemilla pubescens in Lithuania (SNARSKIS, 1939), illustrating the territory of Lithuania researched by P. Snarskis until 1939: 1 - Lithuanian state borderline with Poland (1922-1939); 2 - the border of eastern Lithuania, recognised by the Soviet Russia-Lithuania Peace Treaty (1920), and reclaiming ethnic Lithuanian lands 
known at the time of collection or their prevalence in Lithuania was very limited. This may have caused P. Snarskis to set aside the specimens for further investigation. One of the most critical findings in this Poaceae collection was a new and the oldest location record of Glyceria lithuanica in Lithuania, collected by P. Snarskis in 1960, near Pagiriai Railway Station, Kaišiadorys district. Glyceria lithuanica is distributed only in the south-eastern and north-eastern parts of Lithuania; it was thought that it was first discovered in Biržai district in 1984 (GUDŽINSKAS \& SinkeVIČIENĖ, 2002). The specimen collected by P. Snarskis in 1960 is the oldest known record, and it was collected in central Lithuania, slightly to the west of previously known collections. At present, G. lithuanica is a rare protected species in Lithuania (ANonymous, 2020).

Koeleria grandis, Trisetum sibiricum have limited distribution in eastern Lithuania, and Bromopsis erecta has limited prevalence in southern Lithuania. Agrostis vinealis and Catabrosa aquatica form endangered communities in south-eastern Lithuania (BALEVIČIENĖ, 2000; SinKevičIENĖ, 2000). After comparison with the published distribution maps (NatkeviČaitė-Ivanauskiené, 1980; GudžInSKas, 2007a,b), we can conclude that this discovered Poaceae collection by P. Snarskis provided data on new localities of Bromopsis erecta, Festuca ovina var. firmulacea, Festuca polesica, Glyceria lithuanica and Koeleria grandis (Appendix 1; No. 52).

Third, in some cases, complexes of the features of Koeleria specimens did not completely resemble a particular taxon. The taxonomy of Koeleria has long been recognised to be problematic because of the genera's remarkable morphological plasticity and similarity among taxa (WATSON \& DALLWITZ, 1992; ARnow, 1994; BRULlo et al., 2009), which might be a result of polyploidisation (PEČINKA et al., 2006; DiXoN, 2001b) and hybridisation. Specimen No. 48 was determined by P. Snarskis as Koeleria gracilis (accepted name $K$. macrantha (Ledeb.) Schult.). A previously published study (NATKEVIČAITĖ-IVANAUSKIENĖ, 1963) mentioned that K. macrantha was discovered by P. Snarskis in Matuizos village in 1958; however, a later work by the same author (NATKEVIČAITÉIVANAUSKIENE, 1980) revisited the specimen (WI, No. P02207) and the occurrence of the species in Lithuania was rejected. The specimen identified as $K$. mac- rantha (Appendix 1, No. 48) and the previously known specimen (WI, P02207) were collected from the same locality on the same date. The disagreement on the status of the species remains: according to different authors, the species does (LeKAVIČIUS, 1989; GuDŽINSKAS, 1999) or does not (Krall et al., 2003b) occur in Lithuania. Unfortunately, after analysing this specimen, we were not able to confirm the existence of $K$. macrantha in Lithuania. Future fieldwork must be conducted to determine whether this species is present in Lithuania.

Thin leaf sections were prepared to further investigate atypical specimens of Koeleria glauca. In Koeleria species, the configuration of sclerenchyma and chlorenchyma layers and the size of vascular bundles and leaf ridges found in leaf cross-sections (Fig. 2) are thought to be a character of taxonomical value (Vovk, 1977; Conert, 1998; Goremykina, 2013). It is possible that the variation in leaf anatomy occurred as a reaction to different environmental conditions and, therefore, represents different ecotypes. Alternately, the variation may have occurred due to hybridisation between $K$. grandis and $K$. glauca.

The analysis of P. Snarskis collection highlighted the importance of herbarium collections and increased the understanding of high-value specimens held in a section of the herbarium lacking categorisation. It is possible that insufficient funding for herbarium-related research has delayed other important discoveries in Lithuanian botany. The analysis of P. Snarskis collection provided additional insights into the distribution of rare and endangered Poaceae species in Lithuania. Our exploratory morphological analysis of Koeleria specimens increased the understanding of the complex genus and provided new insight for future research.

\section{ACKNOWLEDGEMENTS}

We thank anonymous reviewers, whose comments and suggestions improved the quality of the manuscript, and Dr Jonè Rukšènienè for identification of Cladosporium hyphae on Agrostis stolonifera specimen.

\section{AUTHOR CONTRIBUTIONS}

The specimens were identified by J. Tupčiauskaitė. J. Tupčiauskaitè and R. Rimgailè-Voicik wrote the manuscript and analysed the leaf sections of Koe- 
leria. The specimens were discovered, photographed, and deposited by M. Rasimavičius.

\section{REFERENCES}

Anonymous, 2020: Dèl Lietuvos Respublikos aplinkos ministro $2003 \mathrm{~m}$. spalio $13 \mathrm{~d}$. ịsakymo Nr. 504 „Dèl Lietuvos Respublikos saugomy gyvūnų, augalų ir grybų rūšių sąrašo patvirtinimo" pakeitimo. - Lietuvos Respublikos aplinkos ministro $2020 \mathrm{~m}$. birželio $9 \mathrm{~d}$. įsakymas Nr. D1340 - https://www.e-tar.lt/portal/index.html.

ARnow L.A., 1994: Koeleria macrantha and K. pyramidata (Poaceae): nomenclatural problems and biological distinctions. - Systematic Botany, 19: 6-20.

BALEVIČIENĖ J., 2000: Agrostietum vinealis ShelyagSosonko et al. 1986 - šerialapis smilgynas. - In: BalevičIené J., GudžInskas Z., SinkevičIEnĖ Z. (eds), Lietuvos raudonoji knyga: augalų bendrijos, 19-21. - Vilnius.

BASALYKAS A., 1965: Lietuvos TSR fizinè geografija, 2. - Vilnius.

Bebber D.P., Carine M.A., Wood J.R., Wortley A.H., Harris D.J., Prance G.T., Davidse G., Paige J., Pennington T.D., Robson N.K., ScotLAND R.W., 2010: Herbaria are a major frontier for species discovery. - Proceedings of the National Academy of Sciences, 107(51): 22169-22171.

Berendsohn W.G., Seltmann P., 2010: Using geographical and taxonomic metadata to set priorities in specimen digitization. - Biodiversity Informatics, 7(2): 120-129.

Brullo S., Giusso G.P., Minissale P., 2009. Taxonomic revision of the Koeleria splendens $\mathrm{C}$. Presl group (Poaceae) in Italy based on morphological characters. - Plant Biosystems, 143: 140-161.

Clayton W.D., Vorontsova M.S., Harman K.T., Williamson H., 2006: GrassBase - The Online World Grass Flora, http://www.kew.org/data/ grasses-db .html (accessed 10 December 2019).

Conert H.J., 1998: Poaceae. - In: Hegi G., Illustrierte Flora von Mitteleuropa, 1(3). - Berlin.

Dixon J.M., 2001a: Koeleria macrantha (Ledeb.) Schultes (K. alpigena Domin, K. cristata (L.) Pers. pro parte, $K$. gracilis Pers., K. albescens auct. non DC.). - Journal of Ecology, 88(4): 709-726.

Dixon J.M., 2001b: On the status of the genus Koe- leria Pers. (Poaceae) in Britain. - Watsonia 23: 377-390.

FunK V., 2014: 100 Uses of an Herbarium. Well at least 72 . Available online at: https://www. researchgate.net/publication/245176734_100_ Uses_for_an_Herbarium_Well_at_Least_72 (Accessed 12 October 2019).

GBIF.org, 2020: GBIF Home Page. Available from: https://www.gbif.org [13 September 2020]

GoremyKina E.V., 2013: Osobennosti anatomičeskoj struktury listovyx plastinok nekotoryx stepnyx zlakov Volgogradskoj oblasti. [The leaf blade anatomy of some Volgograd steppe grasses]. Vestnik Volgogradskogo gosudarstvennogo universiteta, ser. 11. Estestvennye nauki, 1(5): $1-16$.

GuDŽINSKAS Z., 1999: Lietuvos induočiai augalai. [Vascular plants of Lithuania] - Vilnius.

GudžInskas Z., 2007a: Stačioji dirsuolè Bromopsis erecta (Huds.) Fourr. - In: RAšomavičIus V. (ed.), Lietuvos raudonoji knyga: 602. - Vilnius.

GUDŽINSKAS Z., 2007b: Lietuvinè monažolè Glyceria lithuanica (Gorski) Gorski. - In: RAšomavičıus V. (ed.), Lietuvos raudonoji knyga: 608. - Vilnius.

GudžInskas Z., SinkevičIenĖ Z., 2002: Glyceria lithuanica (Poaceae) in Lithuania. - Botanica Lithuanica, 8(3): 239-246.

James S.A., Soltis P.S., Belbin L., Chapman A.D., Nelson G., Paul D.L., Collins M., 2018: Herbarium data: global biodiversity and societal botanical needs for novel research. - Applications in Plant Sciences 6: e1024. doi: 10.1002/aps3.1024

Jukonienė I., RasimavičIus M., RičKienė A., SubKaITĖ M., 2018: S.B. Gorskis bryological collection in the herbarium of Vilnius University. - Acta societatis botanicorum Poloniae: 87(3): 1-7.

KellogG E.A., 2015: Flowering plants. Monocots: Poaceae. - In: Kubitski K. (ed.), The Families and Genera of Vascular Plants, 13: 1-416. - Cham.

KLIMAVIČıūté J., 2002: Botanikos mokslo raida Lietuvoje 1919-1943 m. [Development of botany science in Lithuania in 1919-1943]. - Vilnius.

Krall H., Tabaka L., Balevičienė J., 2003a: Agrostis L. - In: KuUsK V., TABAKa L., JankEVIČIENĖ R. (eds), Flora of the Baltic Countries, 3: 282-285. Tartu.

Krall H., Tabaka L., BalevičIEnĖ J., 2003b: Koeleria Pers. - In: KuUsk V., TABAKa L., JANKeviČIENĖ R. 
(eds), Flora of the Baltic Countries, 3: 270-271 Tartu.

KuUsk V., Tabaka L., Jankevičienè R. (eds), 2003: Flora of the Baltic Countries, 3. - Tartu.

LEKAVIČIUS A., 1989: Vadovas Lietuvos augalams pažinti. - Vilnius.

NAtKeVIČAitė-IVanauskienė M., 1963: Varpiniai Gramineae Juss. - In: NatkeviČaitė-IvanauskieNÉ M. (ed.), Lietuvos TSR flora 2: 114-299. Vilnius.

NAtKeViČAitė-Ivanauskienè M., 1980: Papildymai ir pataisymai Lietuvos TSR floros I-V tomams: varpiniai - Gramineae Juss. (Poaceae Barnhart). In: Natkevičaitė-IvanauskienĖ M., JankevičIENĖ R., LEKAVIČIUS A. (eds), Lietuvos TSR flora, 6: 273-285. - Vilnius.

NATKEVIČAItĖ-IVANAuSKIENĖ M., 1994: Lietuvos herbaras. - Lietuvos mokslas 2, 1(2): 66-76, Vilnius.

Pečinka A., Suchánková P., Lysak M.A., TrávníČEK B., DOLEŽEl J., 2006: Nuclear DNA content variation among central European Koeleria taxa. - Annals of Botany, 98: 117-122.

RASIMAVIČIUS M., 2018: XIX a. samanų kolekcija Vilniaus universiteto herbariume [Bryophyte collection of the 19th century in the Herbarium of Vilnius University]. - In: JUKONIENĖ I. (ed.), Briologiniai archyvai - Lietuvos mokslo ir gamtos istorijos paveldas: 31-47. - Vilnius.

Rothmaler W. (Begr.), Jäger E.J., Werner K. (Hrsg.), 2005: Exkursionsflora von Deutschland, 4. Gefäßpflanzen: Kritischer Band. - München.

Scholz, H. 2008: Some comments on the genus Bromus (Poaceae) and three new species. - Willdenowia, 38: 411-422.

SinkEVIČIENĖ Z., 2000: Catabrosetum aquaticae Rübel 1912 - šaltininis smilgaitynas. - In: BALEvičIEnĖ J., GudžInskas Z., SinkeviČIEnĖ Z. (eds), Lietuvos raudonoji knyga: augalų bendrijos, 113 114. - Vilnius.

SinKEVIČIENE Z., 2003: Key to the species of the ge- nus Glyceria R. Brown. - In: KuUsK v., TABAKA L., JANKEVIČIENE R. (eds), Flora of the Baltic Countries, 3: 286-288. - Tartu.

SNARSKis P., 1939: Lietuvos rasakilos (Alchemilla) ir jų išsiplatinimas. - Vytauto Didžiojo universiteto Matematikos-Gamtos fakulteto darbai, 13(2): 183-347.

Soltis P.S., Nelson G., James S.A., 2018: Green digitization: Online botanical collections data answering real world questions. Applications in Plant Sciences 6: e1028.

Soreng R.J., Peterson P.M., Romaschenko K., Davidse G., Teisher J.K., Clark L.G., Barberá P. Gillespie L.J., Zuloaga F.O., 2017: A worldwide phylogenetic classification of the Poaceae (Gramineae) II: an update and a comparison of two 2015 classifications. - Journal of Systematics and Evolution, 55(4): 259-290.

SNYDER T., 2003: The reconstruction of nations: Poland, Ukraine, Lithuania, Belarus, 1569-1999 Yale.

TupČiauskaité J., Rimgailè-VoiciK R., 2020: Professor Povilas Snarskis - life dedicated to the research of Lithuanian flora. - Botanica, 26(1): 101-108.

Tzvelev N.N., 1974: Poaceae Barnh. - In: Fedorov A.A. (ed.), Flora evropejskoj časti SSSR, 1: 117368. - Saint Petersburg.

Tzvelev N.N., 2000: Opredelitel' sosudistyx rastenij severo-zapadnoj Rossii. - Saint Petersburg.

Vorontsova M.S., Clayton W.D., Simon B.K., 2015: Grassroots e-floras in the Poaceae: growing GrassBase and GrassWorld. - PhytoKeys, 48: 73-84.

Vovk A.G., 1977: Koeleria Pers. - In: R. SHeLIAGSosonko (ed.), Zlaki Ukrainy (Anatomo morfologičeskij kariosistematičeskij i ekologo fitocenotičeskij obzor), 186-199. - Kyiv.

Watson L., Dallwitz M.J., 1992: The grass genera OF THE WORLD. - WALLINGFORD. 


\title{
VILNIAUS UNIVERSITETO HERBARIUME NAUJAI ATRASTA POVILO SNARSKIO POA- CEAE ŠEIMOS AUGALŲ KOLEKCIJA
}

\author{
Jūratė TupČIAuskaitė, Radvilė Rimgailė-VoicıK, Mindaugas RasimaviČıus
}

\section{Santrauka}

Straipsnyje analizuojamas Vilniaus universiteto herbariume (WI) rastas P. Snarskio Poaceae šeimos augalų rinkinys, surinktas daugiausia Rytų Lietuvoje 1943-1960 metais. Iš viso 67 herbariuminiuose lapuose buvo identifikuoti 28 rūšių Poaceae šeimos augalai, tarp kurių ir saugoma Glyceria lithuani- ca rūšis. Kolekcijoje rastas G. lithuanica pavyzdys yra pirmas žinomas šios rūšies konstatavimo faktas Lietuvoje. Kolekcija papildo žinias apie netipiškas dažnų Poaceae šeimos rūšių morfologines formas bei retų ir saugomų rūšių paplitimą Rytų ir Pietryčių Lietuvoje.

\section{APPENDIX 1. THE LIST OF SPECIMENS IDENTIFIED IN P. SNARSKIS' COLLECTION WITH LABEL DATA AND NOTES}

1. Agrostis canina L.; dried swamp, Druskininkai, 25 August 1946

P. Snarskis det.: Agrostis, label not handwritten by Snarskis, but signed by him.

Note: individual with dense leaf tufts on nodes (Fig. 1, A); almost no flowers remaining.

2. A. canina L., raised bog, near a lake, Verkiai, Vilnius county, 26 June 1948

P. Snarskis det.: Agrostis.

3. A. canina L., raised bog, near a lake, Verkiai, Vilnius county, 26 June 1948

P. Snarskis det.: Agrostis.

Note: plant colour unusual. Panicle bright yellowish; represents var. varians, currently not accepted (CONERT, 1998).

4. A. canina L., wet meadow, Švenčionys, 1 July 1951

P. Snarskis det.: Agrostis; with pencil faintly written "canina".

Note: identification problematic: no upper lemma present, rhizome dense. Specimen represents var. varians with intermixed features of var. mutica and var. pudica; currently not accepted (CONERT, 1998).

5. A. canina L., drained meadow, Palanga, 5 July 1958

P. Snarskis det.: Agrostis.
6. A. capillaris L., sandy open forest site, Valakupiai, Vilnius, 16 June 1943

Note: in a sheet with $A$. vinealis.

7. A. capillaris L., pine forest, Verkiai, Vilnius county, 26 June 1948

Note: identification problematic; potential hybrid (A. capillaris $\times$ A. stolonifera).

8. A. capillaris L., swampy site, Nemenčinè, 28 June 1952

P. Snarskis det.: Agrostis.

9. A. ×murbeckii Fouill., a meadow near a lake, Papiškès village, Vilnius district, 21 July 1956

P. Snarskis det.: Agrostis; on separate sheet written in pencil: "leaves not rounded, flat";

Note: identification problematic: the middle veins of glumes scabrous in the upper part, but ligules short, 1-2 mm long, triangular with blunt tip, panicle rachises toothed and stolons partly aboveground; potential hybrid (A. capillaris $\times$ A. stolonifera).

10. A. stolonifera L., meadow, Druskininkai, $20 \mathrm{Au}-$ gust 1946

P. Snarskis det.: Agrostis; label not handwritten by Snarskis.

Note: on glumes, lemmas, and the bases of spikelets dark threadlike Cladosporium Link hyphae (det.Dr J. Rukšènienè) present. 
11. A. stolonifera L., meadow, Matuizos Railway Station, 25 June 1958

P. Snarskis det.: Agrostis.

12. A. vinealis Schreb., sandy open forest site, Valakupiai, Vilnius, 16 June 1943

13. A. vinealis Schreb., dry pine forest, Palanga, 8 August 1949

Notes: label not handwritten by Snarskis; panicles brightly red.

14. Alopecurus pratensis L., swampy meadow, Palanga, 4 July 1958

P. Snarskis det.: Alopecurus.

15. A. pratensis L., meadow, Pagiriai Railway Station, Kaišiadorys district, 22 June 1960

P. Snarskis det.: Alopecurus; railway station name not clearly written.

16. Anisantha tectorum (L.) Nevski, on the railway embankment, Druskininkai, 16 July 1950

P. Snarskis det.: Bromus.

17. Bromopsis erecta (Huds.) Fourr., abandoned soil near the railway, Matuizos village, Varena district, 24 June 1958

18. Bromus arvensis L., barren site, Druskininkai, 16 July 1950

P. Snarskis det.: Bromus; habitat written not clearly.

19. B. hordaceus L., by the field, Druskininkai, 28 July 1950

Note: plant unusually high $(92 \mathrm{~cm})$; stem broken into four pieces.

20. Calamagrostis arundinacea (L.) Roth, on the lake slope, Degučiai village, 12 July 1955

P. Snarskis det.: Calamagrostis.

Note: plant unusually short $(55 \mathrm{~cm})$; leaves and stems brown; panicles yellowish, not fully opened.

21. C. canescens (F.H. Wigg.) Roth, swamp near the railway station, Lentvaris, 13 May 1948

P. Snarskis det.: Agrostis.

Note: specimens with unopened greenish panicles.

22. C. canescens (F.H. Wigg.) Roth, forest, Vilkaviškis, 1 July 1952

P. Snarskis det.: Calamagrostis.

23. C. canescens (F.H. Wigg.) Roth, meadow, Obeliai, west of the railway station, 28 June 1958

P. Snarskis det.: Calamagrostis.

24. C. canescens (F.H. Wigg.) Roth, forest, Pagiriai
Railway Station, Kai iadorys district, 22 June 1960

P. Snarskis det.: Calamagrostis.

25. C. stricta (Timm) Koeler, swampy meadow, Verkiai, Vilnius county, 26 June 1948

26. C. stricta (Timm) Koeler, meadow, Obeliai, west of the railway station, 28 June 1958

P. Snarskis det.: Calamagrostis.

Note: only panicle with upper stem collected; in a sheet with $C$. canescens.

27. Catabrosa aquatica (L.) P. Beauv., wet meadow, Druskininkai, 20 August 1946

Note: label not handwritten by P. Snarskis.

28. C. aquatica (L.) P. Beauv., on the bank of Vilnelè River, Markučiai, Vilnius, 18 June 1948

Note: exceptionally large individual; $55 \mathrm{~cm}$ tall; lower panicle branches with $5 \mathrm{~cm}$ gap from the rest of panicle.

29. Corynephorus canescens (L.) P. Beauv., dry sandy abandoned field, Palanga, 8 August 1949

Note: label not handwritten by Snarskis; colour not typical, panicle light green, represents features of var. flavescens; currently not accepted (CONERT, 1998).

30. Festuca ovina L. var. firmulacea (Markgr.-Dannenb.) Stohr, pine forest, Rūkainiai, Vilnius district, 6 July 1960

P. Snarskis det.: Festuca.

31. F. polesica Zapał., Pine forest, Druskininkai, 7 June 1960

P. Snarskis det.: Festuca.

32. Glyceria lithuanica (Gorski) Gorski, forest, Pagiriai railway station, Kaišiadorys district, 3 July 1960

33. Koeleria glauca (Spreng.) DC., pine forest, Švenčionèliai, 26 June 1951

P. Snarskis det.: Koeleria.

Note: reddish-brown colour short $(9-28 \mathrm{~cm})$ plants with tight panicle $(0.5 \mathrm{~cm}$ in diameter $)$. Stem bases distinctly thickened.

34. K. glauca (Spreng.) DC., pine forest, Pabrade, 30 June 1951

P. Snarskis det.: Koeleria.

Note: (?) underground part too long, tenuous, thickenings indistinct.

35. K. glauca (Spreng.) DC., pine forest, Kaltanènai, near Kaltanènai-Švenčionys road, 2 July 1951

P. Snarskis det.: Koeleria. 
Note: (?) Fig. 2, F; stems short (4-17 cm); panicles elliptical: long $(5-10 \mathrm{~cm})$ and wide $(1.5-3 \mathrm{~cm})$ with elongated branches in the middle; leaves brown. Trampling effect on Koeleria morphology (DixON, 2001a).

36. K. glauca (Spreng.) DC., dry pine forest, Dobis, Vilnius county, 2 July 1951

P. Snarskis det.: Koeleria.

Note: plants too darkreddish brown; thickenings of the lower part indistinct.

37. K. glauca (Spreng.) DC., pine forest, Druskininkai, 6 August 1951

P. Snarskis det.: Koeleria.

Note?: plants too dark greyish brown; thickenings of the lower part indistinct.

38. K. glauca (Spreng.) DC., pine forest, Nemenčinè, 11 June 1953

P. Snarskis det.: Koeleria.

Note: reddish-brown colour, too dark; collected unusually - separately (six separate stems); lower stem part thickening large.

39. K. glauca (Spreng.) DC., pine forest, Nemenčinè, 11 June 1953

P. Snarskis det.: Koeleria.

40. K. glauca (Spreng.) DC., dry pine forest, Santaka village, 1 July 1955

P. Snarskis det.: Koeleria.

Note: panicles and stems greyish-yellow, lower leaves reddish-brown.

41. K. glauca (Spreng.) DC., dry pine forest, Santaka village, 1 July 1955

P. Snarskis det.: Koeleria.

Note: dark, reddish brown, large.

42. K. glauca (Spreng.) DC., dry pine forest, Santaka village, 1 July 1955

P. Snarskis det.: Koeleria.

Note: (?) dark, reddish brown.

43. K. glauca (Spreng.) DC., pine forest , Kryžiskis village, Vilnius district, 8 July 1956

P. Snarskis det.: Koeleria; "crist" written faintly in pencil.

Note: vegetative shoots have more than four leaves; thickenings at the base of the stem small, but present. Represents f. glabriculmis; currently not accepted (CONERT, 1998) Fig. 2, D.

44. K. glauca (Spreng.) DC., dry pine forest, approximately 6 km north of Dūkštas, 11 July 1956

P. Snarskis det.: Koeleria.
Note: single stem.

45. K. glauca (Spreng.) DC., pine forest, south of Žeimenė Railway Station, 16 July 1956 Note: leaf section atypical.

46. K. glauca (Spreng.) DC., pine forest near the station, Pažeimenè Railway Station, 17 July 1956

P. Snarskis det.: Koeleria.

Note: (?) stems and panicles reddish-brown, too small.

47. Koeleria Pers., pine forest, approximately $3 \mathrm{~km}$ south of Pažeimene Railway Station, 17 July 1956

P. Snarskis det.: Koeleria.

Note: (?) at first glance as $K$. glauca, but too many shoots at the base of the stem. Leaf section extremely atypical; Fig. 2, E, on the right.

48. Koeleria Pers., pine forest, Matuizos Railway Station, 25 July 1958

P. Snarskis det.: Koeleria gracilis Pers.

Note: (?) at first glance as $K$. glauca; features discussed in the text; extremely atypical, Fig. 2, E, on the left.

49. K. grandis Besser ex Gorski, pine forest, Pabradè, 30 June 1951

P. Snarskis det.: Koeleria.

50. $K$. grandis Besser ex Gorski, pine forest, Švenčionèliai, 1 July 1951

P. Snarskis det.: Koeleria.

51. K. grandis Besser ex Gorski, forest, Kaltanènai, 2 July 1951

P. Snarskis det.: Koeleria.

Note: rhizome intensively branched, vegetative shoots exceed generative.

52. K. grandis Besser ex Gorski, pine forest, Lavariškès Village, July 1952

P. Snarskis det.: Koeleria.

53. $K$. grandis Besser ex Gorski, pine forest, Nemenčinè, 11 June 1953

P. Snarskis det.: Koeleria.

Note: too dark, reddish-brown, too small, especially panicles; found in the same sheet with K. glauca.

54. K. grandis Besser ex Gorski, pine forest, Nemenčinè, Vilnius district, 11 June 1953

P. Snarskis det.: Koeleria.

Note: found in the same sheet with $K$. glauca.

55. K. grandis Besser ex Gorski, pine forest, approximately 8 km north of Dūkštas, 11 July 1956 
P. Snarskis det.: Koeleria.

56. K. grandis Besser ex Gorski, dry pine forest, approximately $3 \mathrm{~km}$ south of Pasmalve Railway Station, Zarasai district, 11 July 1956

P. Snarskis det.: Koeleria.

57. K. grandis Besser ex Gorski, pine forest, approximately $3 \mathrm{~km}$ south of Pažeimenè Railway Station, 17 July 1956

P. Snarskis det.: Koeleria.

58. K. grandis Besser ex Gorski, dry pine forest, approximately $6 \mathrm{~km}$ south of Pažeimenè Railway Station, 17 July 1956

P. Snarskis det.: Koeleria.

59. Lolium temulentum L., wheat field, Lavariškès village, 20 July 1952

P. Snarskis det.: Lolium.

60. Milium effusum L., forest, Pagiriai Railway Station, Kaišiadorys district, 21 May 1960

Note: extremely large; $90 \mathrm{~cm}$ tall, leaves $2 \mathrm{~cm}$ wide.

61. Molinia caerulea (L.) Moench, Park, Palanga, 14 August 1952P. Snarskis det.: Poa.

Note: in a sheet with Poa trivialis; at first glance similar, from a recreational area.
62. Phleum phleoides (L.) H. Karst., Park meadow, Palanga, 14 August 1952

Note: stem too short, $24 \mathrm{~cm}$ in length, curved (Fig. 1, B); from a recreational area.

63. Poa аппиа L., near the street, Antakalnis, Vilnius, 29 August 1951

P. Snarskis det.: Poa.

Note: exceptionally large individual, approximately 30 shoots, $25 \mathrm{~cm}$ in height.

64. P. palustris L., forest, Druskininkai, 16 July 1950 P. Snarskis det.: Poa.

Note: stem branched at the base with two generative stems (50 $\mathrm{cm}$ in length); the main stem broken off (remaining $20 \mathrm{~cm}$ ).

65. P. trivialis L., on the railway embankment, Druskininkai, 16 July 1950

P. Snarskis det.: Bromus.

Note: small plant, found in the same sheet with Anisantha tectorum.

66. P. trivialis L., Park, Palanga, 14 August 1952

P. Snarskis det.: Poa.

67. Trisetum sibiricum Rupr., forest opening, Riešè, Vilnius district, 28 June 1960

Note: single broken generative stem. 